\title{
The worldwide prevalence of the Dupuytren disease: a comprehensive systematic review and meta-analysis
}

Nader Salari ${ }^{1}$, Mohammadbagher Heydari ${ }^{2}$, Masoud Hassanabadi ${ }^{3}$, Mohsen Kazeminia ${ }^{4}$, Nikzad Farshchian ${ }^{5}$, Mehrdad Niaparast ${ }^{6}$, Yousef Solaymaninasab $^{4^{*}}$, Masoud Mohammadi ${ }^{7^{*}}$ (D), Shamarina Shohaimi ${ }^{8}$ and Alireza Daneshkhah ${ }^{9}$

\begin{abstract}
Background: The Dupuytren disease is a benign fibroproliferative disorder that leads to the formation of the collagen knots and fibres in the palmar fascia. The previous studies reveal different levels of Dupuytren's prevalence worldwide; hence, this study uses meta-analysis to approximate the prevalence of Dupuytren globally.

Methods: In this study, systematic review and meta-analysis have been conducted on the previous studies focused on the prevalence of the Dupuytren disease. The search keywords were Prevalence, Prevalent, Epidemiology, Dupuytren Contracture, Dupuytren and Incidence. Subsequently, SID, Maglran, ScienceDirect, Embase, Scopus, PubMed and Web of Science databases and Google Scholar search engine were searched without a lower time limit and until June 2020. In order to analyse reliable studies, the stochastic effects model was used and the $P^{2}$ index was applied to test the heterogeneity of the selected studies. Data analysis was performed within the Comprehensive Meta-Analysis Software version 2.0.

Results: By evaluating 85 studies (10 in Asia, 56 in Europe, 2 in Africa and 17 studies in America) with a total sample size of 6628506 individuals, the prevalence of Dupuytren disease in the world is found as $8.2 \%(95 \% \mathrm{Cl} 5.7-$ 11.7\%). The highest prevalence rate is reported in Africa with $17.2 \%$ (95\% Cl 13-22.3\%). According to the subgroup analysis, in terms of underlying diseases, the highest prevalence was obtained in patients with type 1 diabetes with $34.1 \%$ (95\% Cl 25-44.6\%). The results of meta-regression revealed a decreasing trend in the prevalence of Dupuytren disease by increasing the sample size and the research year $(P<0.05)$.

Conclusion: The results of this study show that the prevalence of Dupuytren disease is particularly higher in alcoholic patients with diabetes. Therefore, the officials of the World Health Organization should design measures for the prevention and treatment of this disease.
\end{abstract}

Keyword: Dupuytren, Prevalence, Meta-analysis

\footnotetext{
* Correspondence: yousef.1375@gmail.com;

Masoud.mohammadi1989@yahoo.com

${ }^{4}$ Student Research Committee, Kermanshah University of Medical Sciences, Kermanshah, Iran

${ }^{7}$ Department of Nursing, School of Nursing and Midwifery, Kermanshah University of Medical Sciences, Kermanshah, Iran

Full list of author information is available at the end of the article
}

(c) The Author(s). 2020 Open Access This article is licensed under a Creative Commons Attribution 4.0 International License, which permits use, sharing, adaptation, distribution and reproduction in any medium or format, as long as you give appropriate credit to the original author(s) and the source, provide a link to the Creative Commons licence, and indicate if changes were made. The images or other third party material in this article are included in the article's Creative Commons licence, unless indicated otherwise in a credit line to the material. If material is not included in the article's Creative Commons licence and your intended use is not permitted by statutory regulation or exceeds the permitted use, you will need to obtain permission directly from the copyright holder. To view a copy of this licence, visit http://creativecommons.org/licenses/by/4.0/ The Creative Commons Public Domain Dedication waiver (http://creativecommons.org/publicdomain/zero/1.0/) applies to the data made available in this article, unless otherwise stated in a credit line to the data. 


\section{Background}

Dupuytren disease is a benign fibroproliferative disorder that results in the formation of collagen knots and fibres in the palmar fascia. The disease was discovered by Felix Plotter in 1614, yet later attributed to Baron Guillaume Dupuytren, a French physician in 1831 [1-3]. Dupuytren disease usually progresses gradually over the years and is irreversible. Dupuytren leads to abnormal flexion of the fingers, involvement of the metocarpophalangeal joints (MCP) and proximal interphalangeal joints (PIP) and can also involve the distal interphalangeal joint (DIP) [3].

In Dupuytren disease, fibrosis usually begins in the palm of the hand and extends to the fingers (the most common involved finger is the ring finger, followed by the little finger, thumb, middle finger and index finger, respectively) [4]. Dupuytren is not usually painful; however, it gradually restricts the movements of fingers in a curved manner by forming firm bands on the palms and fingers [4, 5].

The main cause of Dupuytren is not yet known, but due to the increase in immune cells and associated phenomena in the infected tissue, it is possible that the disease is related to the immune system [5]. However, numerous studies have been conducted on the factors that cause this disease, in which various genetic and environmental factors have been mentioned $[4,6]$. Environmental risk factors include alcohol abuse, smoking, hand injuries, aging and intense physical occupations which involve hands $[7,8]$.

Also, in some diseases, such as hypertension, alcoholism, diabetes, hyperlipidemia, ischemic heart disease, chronic obstructive pulmonary disease (COPD), pulmonary tuberculosis, epilepsy and rheumatoid arthritis (RA), high prevalence of Dupitren has been reported [6-10].

The Dupuytren disease is the most common genetic disorder in connective tissues, and studies have revealed that there is a significant association between the Dupuytren disease, genetics and family history. However, compared to the environmental factors, family history and masculinity have the greatest impact on the disease. The age of onset of Dupuytren disease in people with a positive family history is lower than in patients without a positive family history $[11,12]$.

Although the disease is not dangerous, it can cause disability in patients. People with Dupuytren face many difficulties including washing, picking up objects, wearing gloves, holding objects with hands, putting hands in pockets, keeping hands straight and pain [13]. These difficulties can reduce the quality of life of the patients [14].

Various studies have been conducted on the prevalence of the Dupuytren disease, which have reported a prevalence of between 0.2 and 56\% [15]. However, there is a lack of a comprehensive study with generalized statistics on the prevalence. Considering the significance of this disease and its negative impacts on patients' quality of life, the present study evaluates the prevalence of the Dupuytren disease in the world by using systematic review and meta-analysis.

\section{Methods}

In this systematic review and meta-analysis study, the SID, MagIran, ScienceDirect, Embase, Scopus, PubMed and Web of Science databases and the Google Scholar search engine were searched for related articles. To access the targeted articles, the following search keywords were used: Prevalence, Prevalent, Epidemiology, Dupuytren Contracture, Dupuytren and Incidence. In addition, all possible combinations of these words have been searched. No time constraints were considered in the search process and all related studies were identified and the information of these studies was transferred to the EndNote X8 bibliography management software. Therefore, all possible related articles published by June 2020 were identified and their information were transferred and analysed. In order to maximize the comprehensiveness of the search, the lists of sources used in all relevant articles found in the above search were manually reviewed.

\section{Inclusion criteria}

The studies that examined the prevalence of the Dupuytren disease in the world, the studies that were observational (non-interventional studies), and studies that their full texts were available were included in our analysis.

\section{Exclusion criteria}

Exclusion criteria were as follows: unrelated studies, studies without sufficient data, duplicate articles and studies with an unclear methodology.

\section{Selection process}

Initially, the studies that were repeated in various searched databases were excluded from this study. Subsequently, a list of the titles of all the remaining articles was prepared. In next step, the eligible articles were selected by evaluating the articles in this list. In next step, the screening was conducted by carefully reviewing the title and abstract of the remaining articles and subsequently, irrelevant articles were removed in accordance with the inclusion and exclusion criteria. In the second stage, the evaluation of the suitability of the studies, the full text of the possible relevant articles remaining from the screening stage was examined based on the inclusion and exclusion criteria, and at this stage, unrelated studies were omitted. To avoid bias, all steps of reviewing sources and extracting data were performed by two reviewers independently. In the case of excluding an article, the reason was documented. In cases where there was a disagreement between the two reviewers, the article was reviewed by a third reviewer. 


\section{Qualitative evaluation}

In order to validate and evaluate the credibility of the articles (i.e., methodological validity and results), a checklist related to the type of study was used. STROBE checklists are commonly used to critically evaluate the observational studies such as the present study. The STROBE checklist consists of six general items including title, abstract, introduction, methods, findings and discussion. Some of these items have subitems, and in total this checklist entails 32 items. In fact, these 32 items describe different methodological aspects of a study including title, problem statement, study objectives, type of study, statistical population of the study, sampling method, the appropriate sample size, definition of variables and procedures, data collection tools, statistical analysis methods and findings. Accordingly, the maximum score that can be obtained from the qualitative evaluation in the STROBE is 32 and the cut-off point's score is 16 . Articles with the scores of 16 and above are considered articles with medium or high methodological quality. On the other hand, articles with the score of less than 16 are considered low quality [16]; low-quality articles were excluded from our work.

\section{Data extraction}

The information of all finalized articles included in the systematic review and meta-analysis processes were extracted using a pre-prepared checklist. This checklist included following fields: title of article, name of first author, year of publication, place of study, sample size, prevalence of Dupuytren disease and age.

\section{Statistical analysis}

To evaluate the heterogeneity of the selected studies, the $I^{2}$ index was used (heterogeneities were divided into three categories: less than 25\% (low heterogeneity), 25-

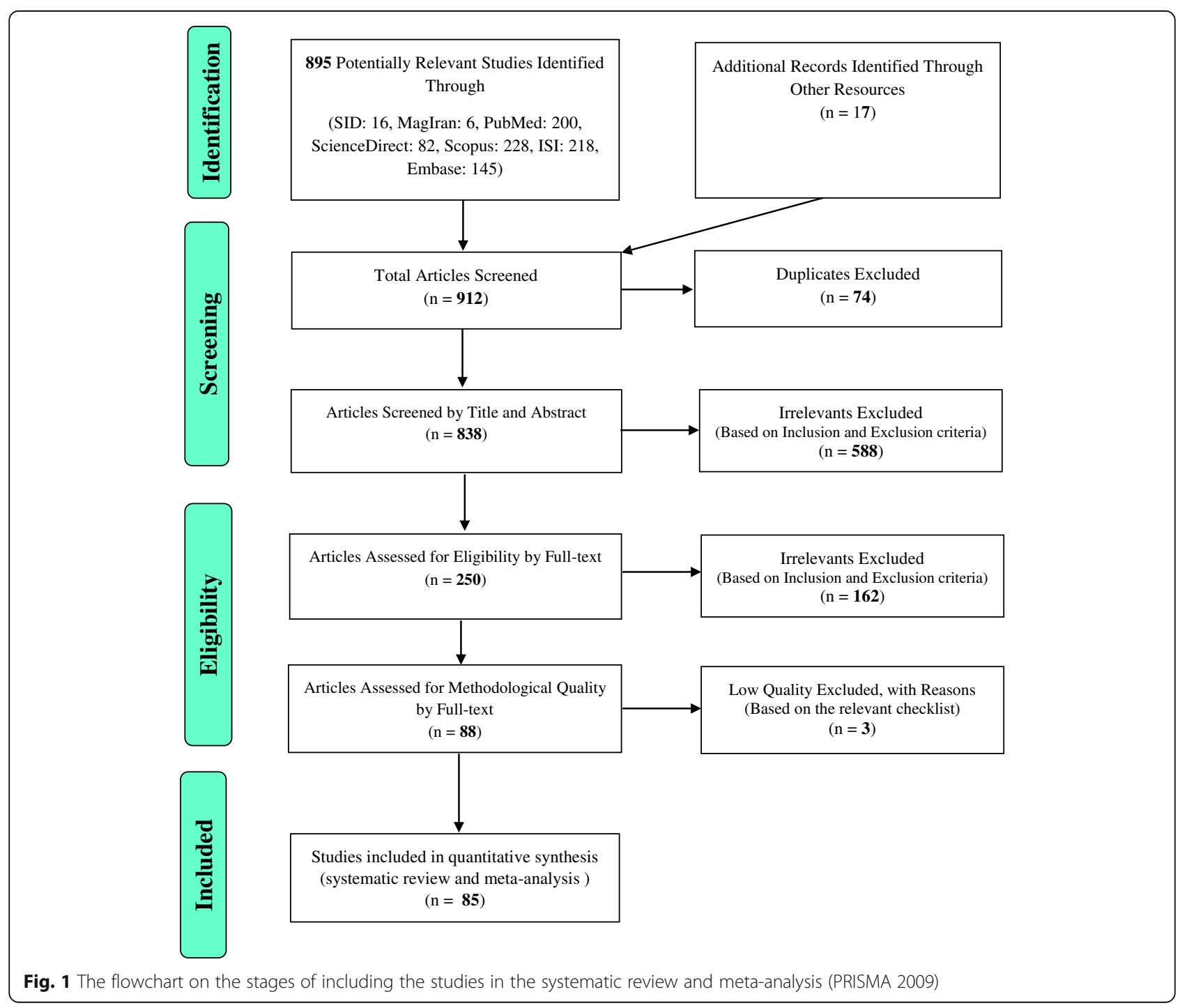


Table 1 Characteristic of included studies prevalence of Dupuytren

\begin{tabular}{|c|c|c|c|c|c|c|c|}
\hline $\begin{array}{l}\text { Author, year, } \\
\text { reference }\end{array}$ & Age (years) & Country & $\begin{array}{l}\text { Sample } \\
\text { size total }\end{array}$ & $\begin{array}{l}\text { Sample } \\
\text { size male }\end{array}$ & $\begin{array}{l}\text { Sample size } \\
\text { female }\end{array}$ & $\begin{array}{l}\text { Prevalence } \\
\%\end{array}$ & Population \\
\hline \multicolumn{8}{|l|}{ Asia } \\
\hline Agrawal et al., 2014, [17] & $\begin{array}{l}3783 \leq 50,1949 \geq \\
50\end{array}$ & India & 5732 & 2516 & 3216 & 7.2 & Diabetic population \\
\hline Kiani et al., 2014, [18] & $\begin{array}{l}54.0 \pm 13.2 \mathrm{Fe}, 51.6 \\
\pm 16.5 \mathrm{Ma}\end{array}$ & Iran & 432 & 134 & 298 & 7.4 & Diabetic population \\
\hline Al-Matubsi et al., 2011, [19] & $51.82 \pm 11.68$ & Jordan & 187 & 77 & 110 & 17.6 & Diabetic population \\
\hline Lee et al., 2018, [20] & $\begin{array}{l}54 \text { men, } 49.5 \text { women } \\
\text { (mean) }\end{array}$ & $\begin{array}{l}\text { South } \\
\text { Korea }\end{array}$ & 16630 & - & - & 3.2 & General population \\
\hline Rajendran et al. (1), 2010, [21] & $53.8 \pm 8.2$ & India & 206 & 98 & 108 & 84.0 & Diabetic population \\
\hline Rajendran et al. (2), 2010, [21] & $52.4 \pm 8.3$ & India & 203 & 106 & 97 & 58.6 & General population \\
\hline Tajica et al., 2014, [22] & $66.7(40-92)$ & Japan & 401 & 163 & 238 & 7.0 & General population \\
\hline Yeh et al., 2015, [23] & $\begin{array}{l}60.7 \pm 18.4 \text { (men) } \\
53.7 \pm 15.5 \text { (women) }\end{array}$ & China & 1078 & 681 & 397 & 8.9 & General population \\
\hline Pandey et al. (1), 2013, [24] & $51.8 \pm 11.5(19-65)$ & India & 200 & 102 & 98 & 19.0 & Diabetic population \\
\hline Pandey et al. (2), 2013, [24] & $53.1 \pm 12.5(19-65)$ & India & 200 & 99 & 101 & 6.0 & General population \\
\hline \multicolumn{8}{|l|}{ Europe } \\
\hline Degreef et al., 2010, [25] & $\geq 50$ & Belgium & 500 & 265 & 235 & 31.6 & General population \\
\hline Gumundsson et al., 1999, [26] & $46-74$ & Norway & 1297 & 1297 & 0 & 19.2 & General population \\
\hline Nordenskjöld et al., 2017, [27] & Over 20 & Sweden & 1300000 & 5208 & 1299 & 0.5 & General population \\
\hline Wijnen et al., 2017, [28] & $\begin{array}{l}\text { Born between } 1900 \\
\text { and } 1999\end{array}$ & Belgium & 215251 & 451 & 274 & 0.3 & General population \\
\hline Arafa et al. (1), 1984, [29] & Over 30 & England & 392 & 131 & 261 & 6.4 & Rheumatoid arthritis \\
\hline Arafa et al. (2), 1984, [29] & Over 30 & England & 555 & 254 & 301 & 16.0 & General population \\
\hline Arafa et al. (3), 1991, [30] & Over 30 & England & 342 & 177 & 165 & 12.0 & $\begin{array}{l}\text { David Lewis Center } \\
\text { Of Epilepsy Patient }\end{array}$ \\
\hline Arafa et al. (4), 1991, [30] & Over 30 & England & 373 & 241 & 132 & 37.8 & $\begin{array}{l}\text { Chalfont Center Of } \\
\text { Epilepsy Patient }\end{array}$ \\
\hline Arkkila et al., 1996, [31] & $\begin{array}{l}33.2 \pm 9.9 \text { type l; } 61.1 \\
\pm 12.4 \text { type } \|\end{array}$ & Finland & 425 & 200 & 225 & 13.9 & Diabetic population \\
\hline Arkkila et al., 2000, [32] & $43.4 \pm 9.5$ & Finland & 28 & 28 & 0 & 32.1 & Diabetes type I \\
\hline Attali et al. (1), 1987, [33] & $54 \pm 18$ & France & 432 & 246 & 186 & 28 & $\begin{array}{l}\text { Different groups } \\
\text { which are named }\end{array}$ \\
\hline Attali et al. (2), 1987, [33] & $58.9 \pm 22.7$ & France & 174 & 77 & 97 & 12.6 & General population \\
\hline Bergenudd et al., 1993, [34] & 55 years old & Sweden & 574 & 255 & 319 & 6.3 & $\begin{array}{l}\text { Light, moderate and } \\
\text { heavy physical } \\
\text { workers }\end{array}$ \\
\hline French et al., 1990, [35] & $23-56$ & England & 50 & 50 & 0 & 6.0 & Patients with HIV \\
\hline Bennett (1), 1982, [36] & $15-64$ & UK & 216 & 216 & 0 & 7.4 & $\begin{array}{l}\text { Manual workers in } \\
\text { bagging and } \\
\text { packing plant }\end{array}$ \\
\hline Bennett (2), 1982, [36] & $15-64$ & UK & 84 & 84 & 0 & 1.2 & $\begin{array}{l}\text { Workers in no } \\
\text { bagging or packing }\end{array}$ \\
\hline Broekstra et al. (1), 2016, [37] & $65-71$ & Netherlands & 169 & 169 & 0 & 51.5 & $\begin{array}{l}\text { Hockey players aged } \\
\text { over } 60 \text { years }\end{array}$ \\
\hline Broekstra et al. (2), 2016, [37] & $59-71$ & Netherlands & 156 & 156 & 0 & 13.5 & General population \\
\hline Burke et al., 2005, [38] & $25-99$ & UK & 97537 & 97537 & 0 & 8.1 & Miners \\
\hline Descatha et al., 2012, & $20-59$ & France & 2161 & 2161 & 0 & 1.2 & Manual workers \\
\hline Descatha et al., 2013, [39] & $59-73$ & France & 13587 & 3570 & 1017 & 7.4 & General population \\
\hline Edington et al. (1), 1991, [40] & $62 \pm 9$ & UK & 200 & 124 & 76 & 23.5 & Diabetic population \\
\hline
\end{tabular}


Table 1 Characteristic of included studies prevalence of Dupuytren (Continued)

\begin{tabular}{|c|c|c|c|c|c|c|c|}
\hline $\begin{array}{l}\text { Author, year, } \\
\text { reference }\end{array}$ & Age (years) & Country & $\begin{array}{l}\text { Sample } \\
\text { size total }\end{array}$ & $\begin{array}{l}\text { Sample } \\
\text { size male }\end{array}$ & $\begin{array}{l}\text { Sample size } \\
\text { female }\end{array}$ & $\begin{array}{l}\text { Prevalence } \\
\%\end{array}$ & Population \\
\hline Edington et al. (2), 1991, [40] & $58 \pm 6$ & UK & 170 & 103 & 67 & 24.7 & General population \\
\hline Finsen et al., 2001, [41] & Over 50 & Norway & 456 & 261 & 195 & 7.7 & General population \\
\hline Gamstedt et al., 1993, [42] & $\begin{array}{l}\text { 19-62 } \\
\text { (mean 42) }\end{array}$ & Sweden & 99 & 49 & 50 & 16.2 & Diabetic population \\
\hline Kristján et al., 2000, [43] & Over 45 & Iceland & 2165 & 1297 & 868 & 13.3 & General population \\
\hline Carson et al., 1993, [44] & $\begin{array}{l}65 \text { to } 97 \\
\text { (mean } 76.2 \text { ) }\end{array}$ & UK & 400 & 400 & 0 & 13.8 & $\begin{array}{l}\text { Ex-military service } \\
\text { pensioners }\end{array}$ \\
\hline Khan et al., 2004, [45] & Over 40 & $\begin{array}{l}\text { England and } \\
\text { Wales }\end{array}$ & 502493 & 502493 & 0 & 0.03 & General population \\
\hline Kovacs et al. (1), 2012, [46] & $52.46 \pm 13.56$ & Romania & 187 & 93 & 94 & 26.7 & Diabetic population \\
\hline Kovacs et al. (2), 2012, [46] & $51.19 \pm 16.21$ & Romania & 197 & 97 & 100 & 5.6 & General population \\
\hline Lanting et al., 2013, & $50-89$ & Netherlands & 763 & 348 & 415 & 22.1 & General population \\
\hline Lennox et al., 1993, [47] & Over 60 & Scotland & 200 & 100 & 100 & 30.0 & $\begin{array}{l}\text { Consecutive geriatric } \\
\text { patients }\end{array}$ \\
\hline Noble et al. (1), 1992, [48] & Over 30 & England & 100 & & & 28.0 & Alcoholic patients \\
\hline Noble et al. (2), 1992, [48] & Over 30 & England & 82 & & & 22.0 & $\begin{array}{l}\text { Hepatic } \\
\text { non-alcoholic patient }\end{array}$ \\
\hline Noble et al. (3), 1992, [48] & Over 30 & England & 100 & & & 8.0 & General population \\
\hline Palmer et al., 2015, [49] & $16-64$ & UK & 4969 & 4969 & 0 & 1.4 & General population \\
\hline Patri et al., 1986, [50] & $20-90$ & France & 155 & 76 & 79 & 9.0 & General population \\
\hline Ramchurn et al., 2009, [51] & 55 & UK & 96 & 60 & 36 & 12.5 & Diabetic population \\
\hline Thomas and Clarke, 1992, [52] & $25-85$ & UK & 500 & 499 & 1 & 13.6 & General population \\
\hline Caffiniire et al., 1983, [53] & $20-65$ & France & 5206 & 5206 & 0 & 3.8 & Iron workers \\
\hline Zerajic and Finsen, 2004, [54] & Over 50 & $\begin{array}{l}\text { Bosnia and } \\
\text { Herzegovina }\end{array}$ & 1207 & 610 & 597 & 25.2 & General population \\
\hline Bulfoni (1), 1980, [55] & - & Italy & 125 & - & - & 72.0 & Alcoholic cirrhosis \\
\hline Bulfoni (2), 1980, [55] & - & Italy & 185 & - & - & 37.8 & $\begin{array}{l}\text { Hepatic alcoholic } \\
\text { involvement without } \\
\text { cirrhosis }\end{array}$ \\
\hline Bulfoni (3), 1980, [55] & - & Italy & 163 & - & - & 23.9 & $\begin{array}{l}\text { Alcoholism without } \\
\text { hepatic involvement }\end{array}$ \\
\hline Diris et al., 2003, [56] & - & France & 100 & - & - & 7.0 & Diabetic population \\
\hline Renard et al. (1), 1994, [57] & - & France & 60 & & & 35.0 & Diabetic type I \\
\hline Renard et al. (2), 1994, [57] & - & France & 60 & & & 30.0 & Diabetic type II \\
\hline Renard et al. (3), 1994, [57] & - & France & 120 & & & 6.7 & General population \\
\hline Stradner et al., 1987, [58] & - & UK & 100 & & & 42.0 & Diabetic population \\
\hline Trybus et al., 2012, [59] & - & Poland & 101 & & & 14.9 & General population \\
\hline Sari, 2013, [60] & $51.14 \pm 15.85$ & Turkey & 21450 & 6477 & 14973 & 0.04 & $\begin{array}{l}\text { Physiotherapy and } \\
\text { rehabilitation }\end{array}$ \\
\hline Ardic et al. (1), 2002, [61] & $\begin{array}{l}57.8 \pm 11.9 \\
(32-81)\end{array}$ & Turkey & 78 & 23 & 55 & 21.8 & Diabetic population \\
\hline Ardic et al. (2), 2002, [61] & $\begin{array}{l}55.7 \pm 11.5 \\
(30-79)\end{array}$ & Turkey & 37 & 10 & 27 & 2.7 & General population \\
\hline Aydeniz et al. (1), 2008, [62] & $58.0 \pm 9.1$ & Turkey & 102 & 44 & 58 & 12.7 & Diabetic population \\
\hline Aydeniz et al. (2), 2008, [62] & $60.1 \pm 7.6$ & Turkey & 101 & 50 & 51 & 3.9 & General population \\
\hline Cakir et al., 2003, [63] & $46 \pm 12(20-76)$ & Turkey & 137 & 26 & 11 & 8.8 & Thyroid disease \\
\hline
\end{tabular}


Table 1 Characteristic of included studies prevalence of Dupuytren (Continued)

\begin{tabular}{|c|c|c|c|c|c|c|c|}
\hline $\begin{array}{l}\text { Author, year, } \\
\text { reference }\end{array}$ & Age (years) & Country & $\begin{array}{l}\text { Sample } \\
\text { size total }\end{array}$ & $\begin{array}{l}\text { Sample } \\
\text { size male }\end{array}$ & $\begin{array}{l}\text { Sample size } \\
\text { female }\end{array}$ & $\begin{array}{l}\text { Prevalence } \\
\%\end{array}$ & Population \\
\hline \multicolumn{8}{|l|}{ Africa } \\
\hline $\begin{array}{l}\text { Beighton and Valkenburg, 1974, } \\
\text { [64] }\end{array}$ & Over 35 & South Africa & 111 & 63 & 48 & 13.5 & General population \\
\hline Mustafa et al., 2016, [65] & $\begin{array}{l}57.8 \pm 9.5 \\
\text { (range 23-88) }\end{array}$ & South Africa & 1000 & 478 & 522 & 18.6 & Diabetic population \\
\hline \multicolumn{8}{|l|}{ America } \\
\hline $\begin{array}{l}\text { Barton and Barton (1), } \\
\text { 2012, [66] }\end{array}$ & $\begin{array}{l}48 \pm 13 \mathrm{M} / 51 \\
\pm 14 \mathrm{~W}\end{array}$ & USA & 294 & 188 & 106 & 1.0 & $\begin{array}{l}\text { Hemochromatosis } \\
\text { probands with HFE } \\
\text { C282Y homozygosity }\end{array}$ \\
\hline $\begin{array}{l}\text { Barton and Barton (2), } \\
\text { 2012, [66] }\end{array}$ & $\begin{array}{l}48 \pm 13 \mathrm{M} / 51 \\
\pm 15 \mathrm{~W}\end{array}$ & USA & 67 & 39 & 28 & 1.5 & $\begin{array}{l}\text { Hemochromatosis } \\
\text { probands with } \\
\text { C282y/H63d } \\
\text { compound } \\
\text { heterozygosity }\end{array}$ \\
\hline Dibenedetti et al., 2011, [67] & Over 18 & USA & 23103 & 11420 & 11683 & 2.0 & General population \\
\hline Diep et al., 2015, [68] & Over 18 & USA & 827 & 353 & 474 & 37.0 & $\begin{array}{l}\text { Asymptomatic } \\
\text { patients }\end{array}$ \\
\hline Robert et al., 1977, [69] & 29-80 (mean 57) & USA & 55 & 13 & 42 & 10.9 & Rheumatoid arthritis \\
\hline Larkin et al., 2014, [70] & $52.2 \pm 6.9$ & USA & 1217 & 633 & 584 & 8.6 & Diabetes type I \\
\hline Patel et al., 2014, [71] & $59.1 \pm 12.90$ & USA & 97 & 51 & 46 & 19.6 & $\begin{array}{l}\text { Patients with } \\
\text { psoriasis }\end{array}$ \\
\hline Alesia et al., 1999, [72] & Over 25 & USA & 324300 & & & 0.3 & General population \\
\hline Su et al. (1), 1972, [73] & - & USA & 142 & 142 & 0 & 12.0 & General population \\
\hline Su et al. (2), 1972, [73] & - & USA & 130 & 130 & 0 & 19.2 & $\begin{array}{l}\text { Alcoholic without } \\
\text { cirrhosis }\end{array}$ \\
\hline Su et al. (3), 1972, [73] & - & USA & 133 & 133 & 0 & 18.0 & $\begin{array}{l}\text { Alcoholic with } \\
\text { cirrhosis }\end{array}$ \\
\hline Weinstein et al. (1), 2011, [74] & Over 40 & USA & 220748 & - & - & 0.5 & Hispanic population \\
\hline Weinstein et al. (2), 2011, [74] & Over 40 & USA & 137205 & - & - & 0.3 & Black population \\
\hline Weinstein et al. (3), 2011, [74] & Over 40 & USA & 118909 & - & - & 0.3 & White population \\
\hline Weinstein et al. (4), 2011, [74] & Over 40 & USA & 70058 & - & - & 0.3 & Asian population \\
\hline Weinstein et al. (5), 2011, [74] & Over 40 & USA & 2055 & - & - & 0.3 & Native American \\
\hline Weinstein et al. (6), 2011, [74] & Over 40 & USA & 607119 & - & - & 0.4 & Other population \\
\hline
\end{tabular}

75\% (moderate heterogeneity) and more than 75\% (high heterogeneity)). In order to test the publication bias and also due to the high volume of samples included in the study, Begg's test was used at a significance level of 0.1, and corresponding funnel plots were drawn. Statistical sensitivity analysis was conducted to evaluate the effect of individual studies on the final results. In this study, meta-regression was used for additional analysis, to examine the relationship between the prevalence of the Dupuytren disease with the sample size and the year of the study. Data analysis was performed using the Comprehensive Meta-Analysis Software (version 2.0).

\section{Results}

The data extracted from the previous studies on the prevalence of the Dupuytren disease were evaluated using a systematic review and meta-analysis. The work has been conducted in accordance with the Preferred Reporting Items for Systematic Reviews and Meta-Analyses (PRIS MA) guidelines. Based on the initial search in the databases, 895 potentially related articles were identified and transferred into the EndNote bibliography management software. Seventeen further studies were also added through other sources. Of the total 912 studies identified, 74 were duplicates and were therefore excluded. In the screening phase, out of 838 remaining studies, 588 articles were removed through the study of titles and abstracts and according to the inclusion and exclusion criteria. In the eligibility evaluation stage, out of the remaining 250 studies, 162 articles were omitted due to irrelevance and after examining the full text of the article and similarly by considering the inclusion and exclusion criteria. At the 
quality evaluation stage, by reviewing the full text of the article and based on the score obtained from the STROBE checklist, out of the remaining 88 studies, 3 studies were excluded due to low methodological quality. These articles obtained the scores of less than 16 based on the STROBE checklist (Fig. 1). Hence, the total number of 85 articles was included in the final analysis stage.

Based on the results from the $I^{2} 99.9$ test and considering the heterogeneity of the selected studies, the random effects model was used to amalgamate the results of the selected studies to approximate the common prevalence. The heterogeneity of the studies could be due to the differences in sample size, sampling error, year of the study or place of study. Of the 85 included articles in systematic review and meta-analysis with a sample size of 6628506 people, 10 studies were conducted in Asia, 56 in Europe, 2 in Africa and 17 in the Americas. The lowest and highest sample sizes were related to the studies of Ardic et al. $(n=37)$ [61] and Nordenskjöld et al. $(n=1,300,000)$, respectively [27]. The characteristics of the included studies in metaanalysis are presented in Table 1.

The probability of publication bias in the dissemination of the results of Dupuytren disease in the world was performed by Begg's test (Begg and Mazumdar) at a significance level of 0.1 , and through examining the corresponding Funnel plots. The results revealed no publication bias in the present study $(P=0.989)$ (Fig. 2).

According to the results of the present study, the prevalence rate of the Dupuytren disease in the world is 8.2\% (95\% CI 5.7-11.7\%). The midpoint of each segment shows the prevalence in each study and the diamond shape shows the prevalence in the population of the entire studies (Fig. 3).

\section{Meta-regression test}

In order to investigate the effects of potential factors affecting the heterogeneity of the prevalence of the Dupuytren disease, meta-regression was used for the two factors of sample size and year of study (Figs. 4 and 5). According to Fig. 4, by increasing of sample size, the prevalence of the Dupuytren in the world decreases, which has a statistically significant difference $(P<0.05)$. Moreover, as reported in Fig. 5, with the increase of the year of the study, the prevalence of the Dupuytren in the world decreases; this difference is also statistically significant $(P<0.05)$.

\section{Subgroup analysis}

Table 2 reports the variations of the prevalence of the Dupuytren disease in different continents. The highest ratio is $17.2 \%$ which belongs to Africa (95\% CI 13$22.3 \%)$. Table 3 reports the prevalence of the Dupuytren disease based on the underlying diseases. These variations are reported in the general population; diabetic population; patients with diabetic type I, diabetic type II and rheumatoid arthritis; and alcoholic patients. The highest rate is among patients diagnosed with type 1 diabetes with $34.1 \%$ (95\% CI 25-44.6\%).

\section{Discussion}

Dupuytren is a hand deformity that usually progresses over several years. This condition affects a layer of tissue under the skin of the palm. Tissue knots form under the

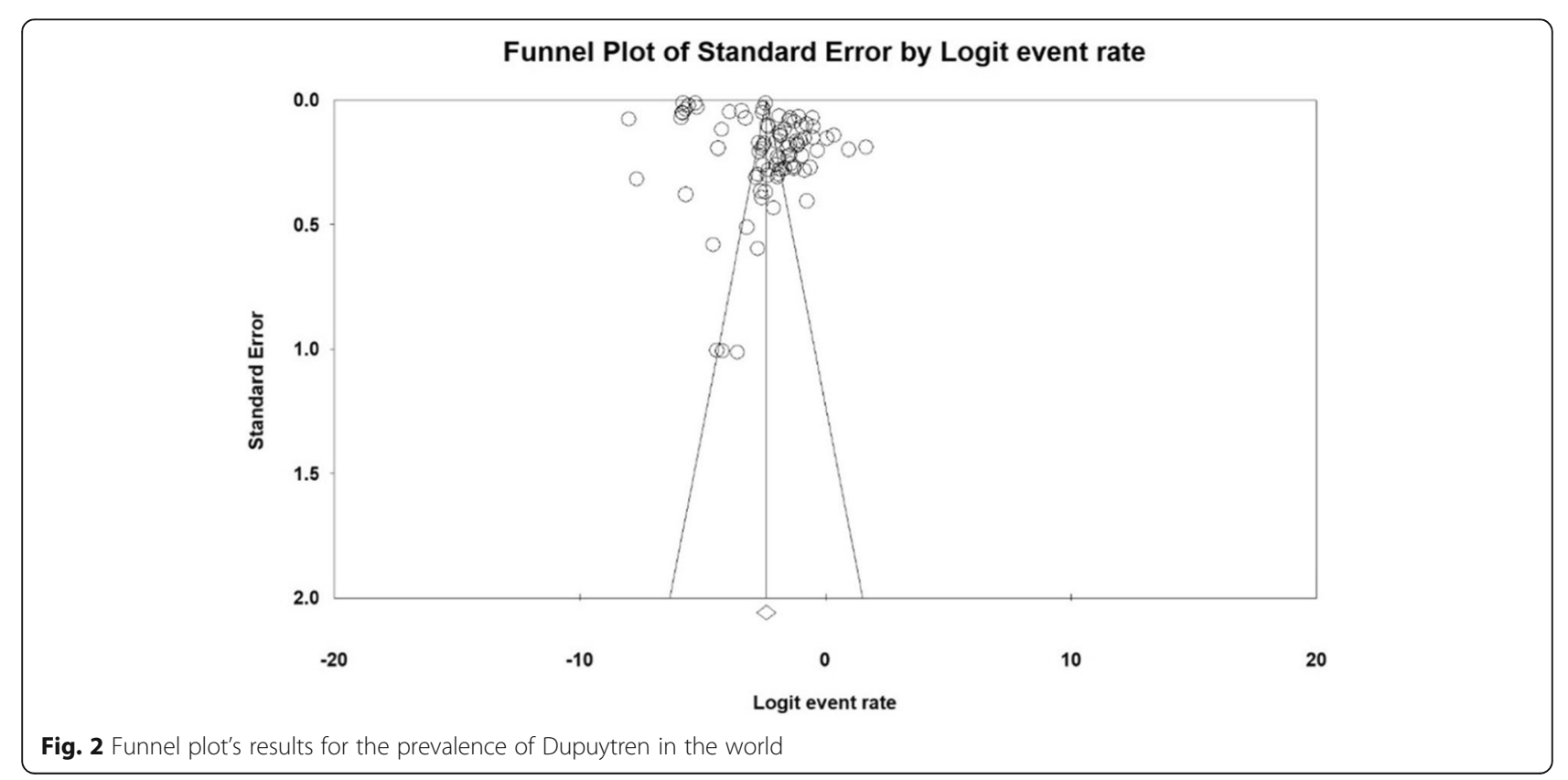




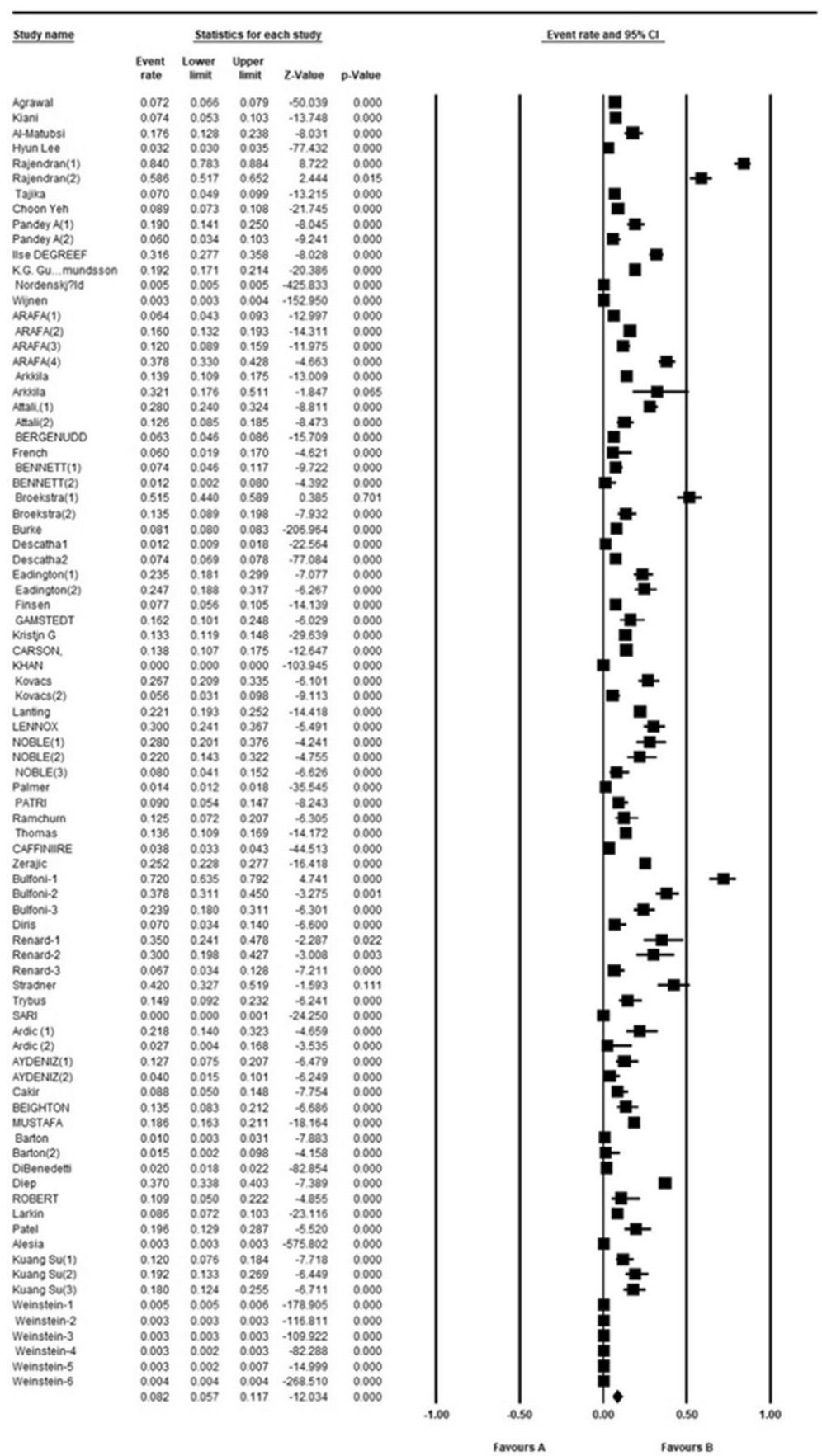

\section{Meta Analysis}

Fig. 3 The global prevalence of the Dupuytren disease at 95\% confidence interval

skin and eventually create a thick cord that can bend one or more fingers. This results in the patient not being able to completely straighten the affected fingers [20]. Dupuytren can make it difficult to use hands to perform certain tasks. Since the thumb and the forefinger are not usually affected, many people do not have much discomfort or inability to perform motor activities such as writing. Yet, with the progression of the disease, the ability 


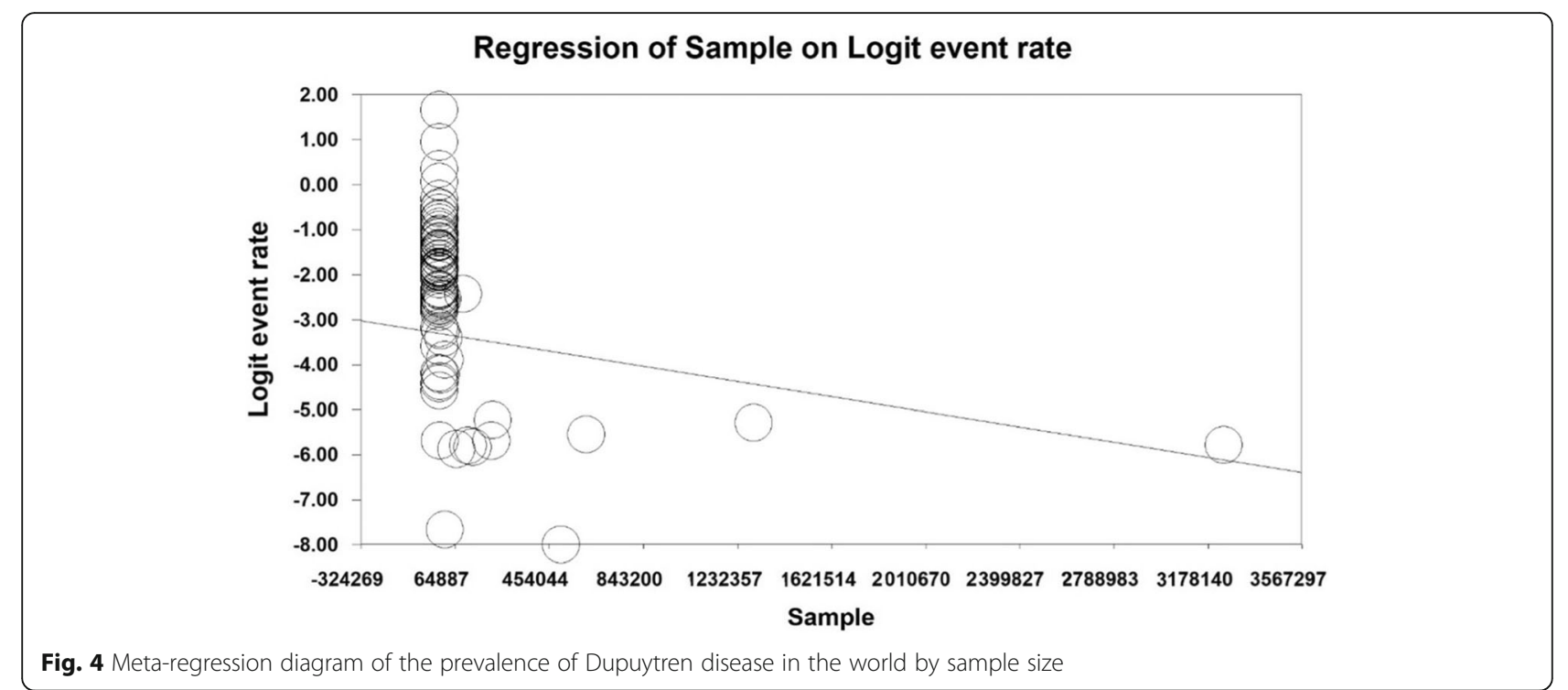

to use the hands becomes limited [37]. The risk factors for Dupuytren include aging (Dupuytren usually occurs after the age of 50), gender, smoking and alcohol consumption, diabetes, family history and geographic location [28]. Due to the significance of this disease and the lack of general statistics on its status worldwide, the aim of this study was to determine the prevalence of the Dupuytren disease in the world through a systematic review and meta-analysis study.

According to the present study, the prevalence of Dupuytren disease in the world is $8.2 \%$ (95\% CI $5.7-$ $11.7 \%)$. The highest prevalence of Dupuytren disease was related to the study of Rajendran et al. [21] with $84 \%$ and the lowest prevalence was related to the study of Weinstein et al. [74] with $0.3 \%$. In a meta-analysis conducted by Lanting et al. [75], the prevalence of
Dupuytren in the Western countries was reported as 66.31\% [75]. Also, Carloni et al. [76], using a meta-analysis work, reported this rate as 1-5.9\% [76]. Our study findings are almost in line with these research works. However, the cause of the minor differences between the present study and these pieces of research can be justified based on the number of articles reviewed in the present study which is higher ( 85 articles in the present study vs. 17 articles in the study of Carloni et al. [76] and 23 articles in the study of Lanting et al. [75]). Moreover, the present study examined patients with different races and geographical locations worldwide.

Due to the change in the demographics in different countries around the world, it is essential to carefully examine the prevalence of Dupuytren disease to acknowledge policy-makers. This can lead to raise more awareness to the

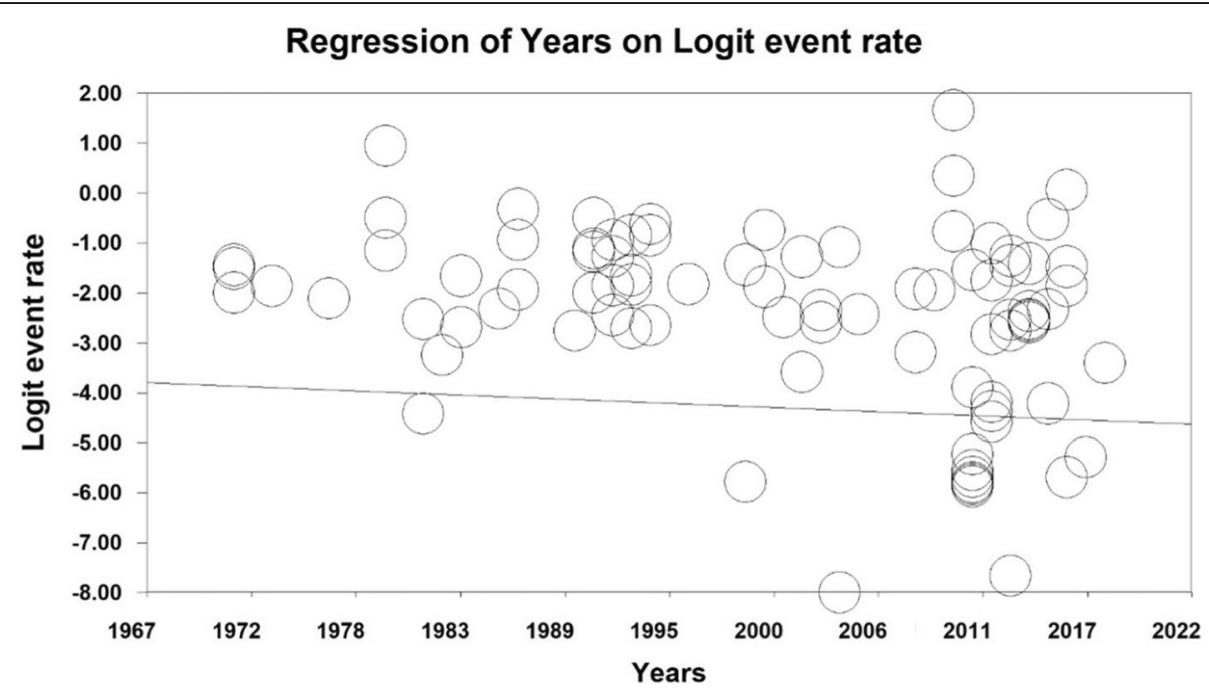

Fig. 5 Meta-regression diagram of the prevalence of Dupuytren disease in the world by year of study 
Table 2 The prevalence of the Dupuytren in the population of different continents

\begin{tabular}{llllll}
\hline Continents & Number of articles & Sample size & $\boldsymbol{I}^{\mathbf{2}}$ & Begg and Mazumdar test & Prevalence \% (95 \% Cl) \\
\hline Asia & 10 & 25269 & 99.3 & 1.000 & $15.3(95 \% \mathrm{Cl} 7.5-28.5)$ \\
Europe & 56 & 2176967 & 99.8 & 0.012 & $10.3(95 \% \mathrm{Cl} 6.4-16.2)$ \\
Africa & 2 & 1111 & 42 & - & $17.2(95 \% \mathrm{Cl} 13-22.3)$ \\
America & 17 & 4425159 & 99.8 & 0.773 & $2.3(95 \% \mathrm{Cl} 1.4-3.8)$ \\
\hline
\end{tabular}

disease's processes and consequences. Therefore, according to the subgroups analysis based on different continents, the highest rate of the prevalence of Dupuytren is related to the African continent with $17.2 \%$ (95\% CI 13-22.3\%), and the lowest is related to the American continent with 2.3\% (95\% CI 1.4-3.8\%).

According to the subgroup's analysis of the underlying diseases, the highest prevalence is primarily in patients with type I diabetes with $34.1 \%$. The second highest rate is among patients with type II diabetes with $25.1 \%$. Diabetes is one of the most common metabolic diseases, in which hyperglycemia causes pathophysiological changes in various organs. Diabetes is a disease with systemic involvement which includes musculoskeletal problems such as Dupuytren. This is more common in diabetic patients compared to the general population [77]. Dupuytren disease is somewhat preventable and treatable, but not completely cured [78]. Therefore, diagnosis, prevention and treatment of this complication are essential. It is recommended that musculoskeletal examination is included as part of periodic care in diabetic patients.

Furthermore, according to the subgroup's analysis of the underlying diseases, the highest prevalence of the disease, after diabetic patients, is related to alcoholic patients (24\%). Various studies reveal that the prevalence of Dupuytren in alcoholics is higher than the general population; however, the cause is still not clear $[79,80]$. Alcohol consumption and its misuse as a social harm have complex interconnected economic, social and cultural causes and have serious safety and health consequences for the society. Therefore, it requires a comprehensive and unified plan along with cooperation between various governing departments.

The most comprehensive study in terms of sample size is the research work conducted by Nordenskjöld et al. in Sweden [27]. They reported prevalence of Dupuytren disease as $0.5 \%$ which differs from the findings of our work. However, it is consistent with the results of metaregression analysis, which revealed that by increasing the sample size and study year, the prevalence rate in the world decreases. According to the results of meta-regression, with the increase of the study year, the prevalence of the world decreases. This reduction can be associated with appropriate preventive measures such as controlling diabetes and blood sugar, avoiding smoking and alcohol consumption and treatment of liver disease.

Dupuytren disease has considerable negative consequences for the patients. Hence, it is important to take measures to achieve effective or supportive treatments to reduce the symptoms of the disease. In addition, in recent years, studying musculoskeletal conditions have been considered an important issue in health care. Since these studies can provide useful information for health care providers and enhance health and therapeutic interventions to improve the quality of services. Ultimately these could lead to improving the quality of life of the patients [81-83].

\section{Limitations}

It can be highlighted that some samples were not based on random selection which, to some extent, appeared as a limitation. Also, other limitations can be signified such as variations in presenting the findings of articles, implementation methods and inaccessibility of the full text of the papers which are presented at the conferences.

\section{Implication}

The results of this study reveal that the prevalence of Dupuytren disease is high, particularly in alcoholic patients with diabetes. Therefore, the officials of the World Health Organization (WHO) are required to develop measures for the prevention and treatment of this disease.

Table 3 Prevalence of Dupuytren disease in the population by underlying diseases

\begin{tabular}{llllll}
\hline Continents & Number of articles & Sample size & $\boldsymbol{I}^{\mathbf{2}}$ & Begg and Mazumdar test & Prevalence \% (95 \% Cl) \\
\hline Diabetic population & 15 & 10161 & 97.9 & 0.843 & $18.1(95 \% \mathrm{Cl} 11.8-26.7)$ \\
General population & 32 & 5329922 & 99.9 & 0.011 & $6.4(95 \% \mathrm{Cl} 3.8-10.5)$ \\
Diabetic type I & 2 & 88 & 0 & - & $34.1(95 \% \mathrm{Cl} 25-44.6)$ \\
Diabetic type II & 2 & 260 & 3.3 & - & $25.1(95 \% \mathrm{Cl} 20.1-31)$ \\
Rheumatoid arthritis & 2 & 447 & 33.1 & - & $7.5(95 \% \mathrm{Cl} 4.6-12)$ \\
Alcoholic patient & 5 & 693 & 81.4 & 0.220 & $24.0(95 \% \mathrm{Cl} 17.2-32.3)$ \\
\hline
\end{tabular}




\section{Abbreviations}

WHO: World Health Organization; MCP: Metocarpophalangeal; PIP: Proximal interphalangeal; DIP: Distal interphalangeal; COPD: Chronic obstructive pulmonary disease; RA: Rheumatoid arthritis; SID: Scientific Information Database; PRISMA: Preferred Reporting Items for Systematic Reviews and Meta-Analysis; STROBE: Strengthening the Reporting of Observational Studies in Epidemiology for cross-sectional Study

\section{Acknowledgements}

We hereby express our gratitude and appreciation to the Student Research Committee of Kermanshah University of Medical Sciences.

\section{Authors' contributions}

$\mathrm{ND}, \mathrm{MBH}, \mathrm{MH}$ and $\mathrm{MK}$ contributed to the design. MM contributed to the statistical analysis and participated in most of the study steps. NF, MN and YS prepared the manuscript. SHSH and AD assisted in designing the study and helped in the interpretation of the study. All authors have read and approved the content of the manuscript.

\section{Funding}

By Deputy for Research and Technology, Kermanshah University of Medical Sciences (IR) (3010357), and it had no role in the study process.

\section{Availability of data and materials}

Datasets are available through the corresponding author upon reasonable request.

\section{Ethics approval and consent to participate}

Not applicable.

\section{Consent for publication}

Not applicable.

\section{Competing interests}

The authors declare that they have no conflicts of interest.

\section{Author details}

'Department of Biostatistics, School of Health, Kermanshah University of Medical Sciences, Kermanshah, Iran. Department of General Surgery, Faculty of Medicine, Kermanshah University of Medical Sciences, Kermanshah, Iran. ${ }^{3}$ Lecturer in International Business \& Strategy, Faculty of Business \& Law, University of Northampton, Northampton, UK. ${ }^{4}$ Student Research Committee, Kermanshah University of Medical Sciences, Kermanshah, Iran. ${ }^{5}$ Department of Otolaryngology, School of Medicine, Kermanshah University of Medical Sciences, Kermanshah, Iran. 'Department of Statistics, Razi University, Kermanshah, Iran. ${ }^{7}$ Department of Nursing, School of Nursing and Midwifery, Kermanshah University of Medical Sciences, Kermanshah, Iran. ${ }^{8}$ Department of Biology, Faculty of Science, University Putra Malaysia, Serdang, Selangor, Malaysia. ${ }^{9}$ School of Computing, Electronics and Maths, Coventry University, London, UK

Received: 24 August 2020 Accepted: 1 October 2020

Published online: 28 October 2020

\section{References}

1. Peimer CA, Blazar P, Coleman S, Kaplan FTD, Smith T, Tursi JP, et al. Dupuytren contracture recurrence following treatment with collagenase clostridium histolyticum (CORDLESS Study): 3-Year Data. J Hand Surgery. 2013:38(1):12-22.

2. Pess GM, Pess RM, Pess RA. Results of needle aponeurotomy for Dupuytren contracture in over 1,000 fingers. J Hand Surgery. 2012;37(4):651-6.

3. Peimer CA, Blazar P, Coleman S, Kaplan FTD, Smith T, Lindau T. Dupuytren contracture recurrence following treatment with collagenase clostridium histolyticum (CORDLESS [Collagenase Option for Reduction of Dupuytren Long-Term Evaluation of Safety Study]): 5-Year Data. Journal of Hand Surgery. 2015;40(8):1597-605.

4. Michou L, Lermusiaux J-L, Teyssedou J-P, Bardin T, Beaudreuil J, PetitTeixeira E. Genetics of Dupuytren's disease. Joint Bone Spine. 2012; 79(1):7-12.

5. Shih B, Bayat A. Scientific understanding and clinical management of Dupuytren disease. Nature Reviews Rheumatology. 2010;6(12):715-26.
6. Eckerdal D, Nivestam A, Dahlin LB. Surgical treatment of Dupuytren's disease - outcome and health economy in relation to smoking and diabetes. BMC Musculoskelet Disord. 2014;15:117-23.

7. Morelli I, Fraschini G, Banfi AE. Dupuytren's Disease: Predicting factors and associated conditions. A single center questionnaire-based case-control study. Archives of Bone and Joint Surgery. 2017;5(6):384-93.

8. Descatha A, Bodin J, Ha C, Goubault P, Lebreton M, Chastang JF, et al. Heavy manual work, exposure to vibration and Dupuytren's disease? Results of a surveillance program for musculoskeletal disorders. Occupational and environmental medicine. 2012;69(4):296-9.

9. Broekstra DC, Groen H, Molenkamp S, Werker PM, van den Heuvel ER. A systematic review and meta-analysis on the strength and consistency of the associations between Dupuytren disease and diabetes mellitus, liver disease, and epilepsy. Plastic and reconstructive surgery. 2018; 141(3):367-79.

10. Lanting $R$, van den Heuvel ER, Westerink B, Werker PMN. Prevalence of Dupuytren disease in the Netherlands. Plastic and Reconstructive Surgery. 2013;132(2):394-403.

11. Becker K, Tinschert S, Lienert A, Bleuler P, Staub F, Meinel A, et al. The importance of genetic susceptibility in Dupuytren's disease. Clinical genetics. 2015;87(5):483-7.

12. Dolmans $\mathrm{GH}$, de Bock $\mathrm{GH}$, Werker PM. Dupuytren diathesis and genetic risk. The Journal of Hand Surgery. 2012;37(10):2106 -11-20.

13. Rodrigues J, Zhang W, Scammell B, Davis T. What patients want from the treatment of Dupuytren's disease-is the Unité Rhumatologique des Affections de la Main (URAM) scale relevant? Journal of Hand Surgery (European Volume). 2015;40(2):150-4.

14. Wilburn J, McKenna S, Perry-Hinsley D, Bayat A. The impact of Dupuytren disease on patient activity and quality of life. The Journal of hand surgery. 2013:38(6):1209-14

15. Hindocha S, McGrouther DA, Bayat A. Epidemiological evaluation of Dupuytren's disease incidence and prevalence rates in relation to etiology. Hand. 2009;4(3):256-69.

16. Salari N, Mohammadi M, Vaisi-Raygani A, Abdi A, Shohaimi S, Khaledipaveh B, Daneshkhah A, Jalali R. The prevalence of severe depression in Iranian older adult: a meta-analysis and meta-regression. BMC Geriatrics. 2020;20(1):39-49.

17. Agrawal RP, Gothwal S, Tantia P, Agrawal R, Rijhwani $P$, Sirohi $P$, et al Prevalence of rheumatological manifestations in diabetic population from North-West India. The Journal of the Association of Physicians of India. 2014; 62(9):788-92

18. Kiani J, Goharifar H, Moghimbeigi A, Azizkhani H. Prevalence and risk factors of five most common upper extremity disorders in diabetics. Journal of research in health sciences. 2014;14(1):92-5.

19. Al-Matubsi HY, Hamdan F, Alhanbali OA, Oriquat GA, Salim M. Diabetic hand syndromes as a clinical and diagnostic tool for diabetes mellitus patients. Diabetes research and clinical practice. 2011:94(2):225-9.

20. Lee KH, Kim JH, Lee CH, Kim SJ, Jo YH, Lee M, et al. The epidemiology of Dupuytren's disease in Korea: a nationwide population-based study. Journal of Korean medical science. 2018;33(31):e204

21. Ravindran Rajendran S, Bhansali A, Walia R, Dutta P, Bansal V, Shanmugasundar $\mathrm{G}$. Prevalence and pattern of hand soft-tissue changes in type 2 diabetes mellitus. Diabetes \& metabolism. 2011;37(4):312-7.

22. Tajika T, Kobayashi T, Kaneko T, Tsunoda D, Tsunoda K, Sutou T, et al. Epidemiological study for personal risk factors and quality of life related to Dupuytren's disease in a mountain village of Japan. Journal of orthopaedic science : official journal of the Japanese Orthopaedic Association. 2014;19(1):64-70.

23. Yeh C-C, Huang K-F, Ho C-H, Chen K-T, Liu C, Wang J-J, et al. Epidemiological profile of Dupuytren's disease in Taiwan (Ethnic Chinese): a nationwide population-based study. BMC musculoskeletal disorders. 2015: 16(1):20-7.

24. Pandey A, Usman K, Reddy H, Gutch M, Jain N, Qidwai S. Prevalence of hand disorders in type 2 diabetes mellitus and its correlation with microvascular complications. Annals of medical and health sciences research. 2013:3(3):349-54.

25. Degreef I, De Smet L. A high prevalence of Dupuytren's disease in Flanders. Acta orthopaedica Belgica. 2010;76(3):316-20.

26. Guomundsson KG, Arngrímsson R, Sigfússon N, Jónsson T. Prevalence of joint complaints amongst individuals with Dupuytren's disease - from the Reykjavik study. Scand J Rheumatol. 1999;28(5):300-4. 
27. Nordenskjöld J, Englund M, Zhou C, Atroshi I. Prevalence and incidence of doctor-diagnosed Dupuytren's disease: a population-based study. The Journal of hand surgery, European volume. 2017;42(7):673-7.

28. Degreef I. Comorbidity in Dupuytren disease. Acta orthopaedica Belgica. 2016;82(3):643-8.

29. Arafa M, Steingold RF, Noble J. The incidence of Dupuytren's disease in patients with rheumatoid arthritis. The Journal of Hand Surgery: British \& European Volume. 1984;9(2):165-6.

30. Arafa M, Noble J, Royle SG, Trail IA, Allen J. Dupuytren's and epilepsy revisited. J Hand Surg (GBR). 1992;17(2):221-4.

31. Arkkila PET, Kantola IM, Viikari JSA, Rönnemaa T. Shoulder capsulitis in type I and II diabetic patients: association with diabetic complications and related diseases. ANN RHEUM DIS. 1996:55(12):907-14

32. Arkkila PET, Koskinen PJ, Kantola IM, Rönnemaa T, Seppänen E, Viikari JS. Dupuytren's disease in type I diabetic subjects: investigation of biochemical markers of type III and I collagen. Clin Exp Rheumatol. 2000;18(2):215-9.

33. Attali $P$, Ink $O$, Pelletier $G$, Vernier $C$, Jean F, Moulton $L$, et al. Dupuytren's contracture, alcohol consumption, and chronic liver disease. Archives of internal medicine. 1987;147(6):1065-7.

34. Bergenudd H, Lindgärde F, Nilsson BE. Prevalence of Dupuytren's contracture and its correlation with degenerative changes of the hands and feet and with criteria of general health. Journal of hand surgery (Edinburgh, Scotland). 1993;18(2):254-7.

35. French PD, Kitchen VS, Harris JR. Prevalence of Dupuytren's contracture in patients infected with HIV. BMJ (Clinical research ed). 1990:301(6758):967-77.

36. Bennett B. Dupuytren's contracture in manual workers. BR J IND MED. 1982; 39(1):98-100.

37. Broekstra DC, van den Heuvel ER, Lanting R, Harder T, Smits I, Werker PMN. Dupuytren disease is highly prevalent in male field hockey players aged over 60 years. British journal of sports medicine. 2018;52(20):1327-31.

38. Burke FD, Proud G, Lawson IJ, McGeoch KL, Miles JN. An assessment of the effects of exposure to vibration, smoking, alcohol and diabetes on the prevalence of Dupuytren's disease in 97,537 miners. The Journal of hand surgery, European volume. 2007:32(4):400-6.

39. Descatha A, Carton M, Mediouni Z, Dumontier C, Roquelaure Y, Goldberg M, et al. Association among work exposure, alcohol intake, smoking and Dupuytren's disease in a large cohort study (GAZEL). BMJ Open. 2014;4(1): e004214.

40. Eadington DW, Patrick AW, Frier BM. Association between connective tissue changes and smoking habit in type 2 diabetes and in non-diabetic humans. Diabetes research and clinical practice. 1991;11(2):121-5.

41. Finsen $\mathrm{V}$, Dalen $\mathrm{H}$, Nesheim J. The prevalence of Dupuytren's disease among 2 different ethnic groups in northern Norway. The Journal of hand surgery. 2002;27(1):115-7.

42. Gamstedt A, Holm-Glad J, Ohlson CG, Sundström M. Hand abnormalities are strongly associated with the duration of diabetes mellitus. Journal of internal medicine. 1993;234(2):189-93.

43. Gudmundsson KG, Arngrímsson R, Sigfússon N, Björnsson A, Jónsson T. Epidemiology of Dupuytren's disease: clinical, serological, and social assessment. The Reykjavik Study. Journal of clinical epidemiology. 2000; 53(3):291-6.

44. Carson J, Clarke C. Dupuytren's contracture in pensioners at the Royal Hospital Chelsea. Journal of the Royal College of Physicians of London. 1993;27(1):25-7.

45. Khan AA, Rider OJ, Jayadev CU, Heras-Palou C, Giele H, Goldacre M. The role of manual occupation in the aetiology of Dupuytren's disease in men in England and Wales. The Journal of Hand Surgery: British \& European Volume. 2004;29(1):12-4.

46. Kovacs D, Demian L, Babes A. Prevalence and risk of Dupuytrèn disease in patients with diabetes versus non-diabetic patients. Rom J Diabetes Nutr Metab Dis. 2012;19(4):373-80.

47. Lennox IA, Murali SR, Porter R. A study of the repeatability of the diagnosis of Dupuytren's contracture and its prevalence in the grampian region. Journal of hand surgery (Edinburgh, Scotland). 1993;18(2):258-61.

48. Noble J, Arafa M, Royle SG, McGeorge G, Crank S. The association between alcohol, hepatic pathology and Dupuytren's disease. The Journal of Hand Surgery: British \& European Volume. 1992;17(1):71-4.

49. Palmer KT, D’Angelo S, Syddall H, Griffin MJ, Cooper C, Coggon D. Dupuytren's contracture and occupational exposure to hand-transmitted vibration. Occup Environ Med. 2014:71(4):241-5.
50. Patri B, Gatto A. Raynaud's syndrome, Dupuytren's contracture, force of prehension and sensibility of the hand. A study of the age related variations. Annales de Chirurgie de la Main. 1986;5(2):144-7.

51. Ramchurn N, Mashamba C, Leitch E, Arutchelvam V, Narayanan K, Weaver J, et al. Upper limb musculoskeletal abnormalities and poor metabolic control in diabetes. European journal of internal medicine. 2009;20(7):718-21.

52. Thomas PR, Clarke D. Vibration white finger and Dupuytren's contracture: are they related? Occupational medicine (Oxford, England). 1992;42(3):155-8.

53. de la Caffinière JY, Wagner R, Etscheid J, Metzger F. Travail manuel et maladie de dupuytren: Résultat d'une enquête informatisée en milieu sidérurgique. Annales de Chirurgie de la Main. 1983;2(1):66-72.

54. Zerajic D, Finsen V. Dupuytren's disease in Bosnia and Herzegovina. An epidemiological study. BMC musculoskeletal disorders. 2004;5:10,

55. Bulfoni A. Vascular spiders, palmar erythema and Dupuytren's contracture during alcoholic hepatic cirrhosis. ARCH SCI MED. 1980; 137(2):355-60.

56. Diris N, Colomb M, Leymarie F, Durlach V, Caron J, Bernard P. Non infectious skin conditions associated with diabetes mellitus: a prospective study of 308 cases. Ann Dermatol Venereol. 2003;130(11):1009-14.

57. Renard $\mathrm{E}$, Jacques D, Chammas M, Poirier UL, Bonifacj C, Jaffiol C, et al. Increased prevalence of soft tissue hand lesions in type 1 and type 2 diabetes mellitus: various entities and associated significance. Diabete \& metabolisme. 1994;20(6):513-21.

58. Stradner F, Ulreich A, Pfeiffer KP. Dupuytren's plamar contraction as an attendant disease of diabetes mellitus. WIEN MED WOCHENSCHR. 1987; 137(4):89-92.

59. Trybus M, Bednarek M, Budzyński P, Gniadek M, Lorkowski J. Concomitance of Ledderhose's disease with Dupuytren's contracture. Own experience. Prz Lek. 2012;69(9):663-6.

60. Sari Z, Yurdalan SU, Polat MG, Horoz H, Camcioǧlu B. Prevalence of isolated hand problems in physiotherapy and rehabilitation centres in Istanbul. Fiz Rehab. 2013;24(1):88-92.

61. Ardic F, Soyupek F, Kahraman Y, Yorgancioglu R. The musculoskeletal complications seen in type II diabetics: predominance of hand involvement. Clin Rheumatol. 2003:22(3):229-33.

62. Aydeniz A, Gursoy S, Guney E. Which musculoskeletal complications are most frequently seen in type 2 diabetes mellitus? The Journal of international medical research. 2008;36(3):505-11.

63. Cakir M, Samanci N, Balci N, Balci MK. Musculoskeletal manifestations in patients with thyroid disease. Clinical endocrinology. 2003;59(2):162-7.

64. Beighton P, Valkenburg HA. Bone and joint disorders on Tristan da Cunha. S AFR MED J. 1974;48(17):743-7.

65. Mustafa KN, Khader YS, Bsoul AK, Ajlouni K. Musculoskeletal disorders of the hand in type 2 diabetes mellitus: prevalence and its associated factors. International journal of rheumatic diseases. 2016;19(7):730-5.

66. Barton JC, Barton JC. Dupuytren's contracture in Alabama HFE hemochromatosis probands. Clinical medicine insights Arthritis and musculoskeletal disorders. 2012:5:67-75.

67. Dibenedetti DB, Nguyen D, Zografos L, Ziemiecki R, Zhou X. Prevalence, incidence, and treatments of Dupuytren's disease in the United States: results from a population-based study. Hand (New York, NY). 2011;6(2): 149-58.

68. Diep GK, Agel J, Adams JE. Prevalence of palmar fibromatosis with and without contracture in asymptomatic patients. Journal of plastic surgery and hand surgery. 2015;49(4):247-50.

69. Gray RG, Gottlieb NL. Hand flexor tenosynovitis in rheumatoid arthritis. Prevalence, distribution, and associated rheumatic features. Arthritis and rheumatism. 1977:20(4):1003-8.

70. Larkin ME, Barnie A, Braffett BH, Cleary PA, Diminick L, Harth J, et al. Musculoskeletal complications in type 1 diabetes. Diabetes care. 2014;37(7): 1863-9.

71. Patel M, Freeman NR, Dhaliwal S, Wright N, Daoud Y, Ryan C, et al. The prevalence of Dupuytren contractures in patients with psoriasis. Clinical and experimental dermatology. 2014;39(8):894-9.

72. Saboeiro AP, Pokorny JJ, Shehadi SI, Virgo KS, Johnson FE. Racial distribution of Dupuytren's disease in Department of Veterans Affairs patients. Plast Reconstr Surg. 2000:106(1):71-5.

73. Su CK, Patek AJ Jr. Dupuytren's contracture: its association with alcoholism and cirrhosis. Arch Intern Med. 1970;126(2):278-81. 
74. Weinstein AL, Haddock NT, Sharma S. Dupuytren's disease in the Hispanic population: a 10-year retrospective review. Plastic and reconstructive surgery. 2011;128(6):1251-6.

75. Lanting R, Broekstra DC, Werker PM, van den Heuvel ER. A systematic review and meta-analysis on the prevalence of Dupuytren disease in the general population of Western countries. Plastic and reconstructive surgery. 2014; 133(3):593-603.

76. Carloni R, Gandolfi S, Elbaz B, Bonmarchand A, Beccari R, AuquitAuckbur I. Dorsal Dupuytren's disease: a systematic review of published cases and treatment options. Journal of Hand Surgery (European Volume). 2019:44(9):963-71.

77. Shardha AK, Vaswani AS, Faraz A, Alam MT, Kumar P. Frequency and risk factors associated with hypomagnesaemia in hypokalemic type-2 diabetic patients. Journal of the College of Physicians and Surgeons--Pakistan : JCPSP. 2014;24(11):830-5.

78. Zamani B, Matini SM, Jamali R, Taghadosi M. Frequency of musculoskeletal complications among the diabetic patients referred to Kashan diabetes center during 2009-10. KAUMS Journal (FEYZ). 2011;15(3):225-31.

79. Sakai A, Zenke Y, Menuki K, Yamanaka Y, Tajima T, Uchida S. Current smoking is associated with delayed wound healing but not with improvement of contracture after the open palm technique for Dupuytren's disease. The Journal of Hand Surgery (Asian-Pacific Volume). 2019;24(01):65-71.

80. Grazina R, Teixeira S, Ramos R, Sousa H, Ferreira A, Lemos R. Dupuytren's disease: where do we stand? EFORT Open Reviews. 2019;4(2):63-9.

81. Leung R, Capstick R, Lei A, Nour D, Rozen WM, Hunter-Smith DJ. Morbidity of interventions in previously untreated Dupuytren disease: a systematic review. European Journal of Plastic Surgery. 2019;42(2):111-8.

82. Eiriksdottir A, Atroshi I. A new finger-preserving procedure as an alternative to amputation in recurrent severe Dupuytren contracture of the small finger. BMC musculoskeletal disorders. 2019;20(1):323.

83. Kan HJ, Verrijp FW, Hovius SE, van Nieuwenhoven CA, Group DD, Selles RW. Recurrence of Dupuytren's contracture: a consensus-based definition. PloS one. 2017:12(5):e0164849.

\section{Publisher's Note}

Springer Nature remains neutral with regard to jurisdictional claims in published maps and institutional affiliations.

Ready to submit your research? Choose BMC and benefit from:

- fast, convenient online submission

- thorough peer review by experienced researchers in your field

- rapid publication on acceptance

- support for research data, including large and complex data types

- gold Open Access which fosters wider collaboration and increased citations

- maximum visibility for your research: over $100 \mathrm{M}$ website views per year

At $\mathrm{BMC}$, research is always in progress.

Learn more biomedcentral.com/submissions 